\title{
Contrasting life-histories in two syntopic amphibians of the Leptodactylus fuscus group (Heyer 1978)
}

\author{
FEDERICO MARANGONI ${ }^{1,2}$, AZUL COURTIS ${ }^{1}$, JOSE M. PIÑEIRO ${ }^{1,4}$, MARÍA DEL $^{2}$ \\ ROSARIO INGARAMO ${ }^{1}$, RODRIGO CAJADE ${ }^{1,3}$ and FLORINA STĂNESCU ${ }^{3,5}$
}

\author{
${ }^{1}$ Departamento de Biología, Facultad de Ciencias Exactas y Naturales y Agrimensura, Universidad Nacional del Nordeste/ \\ FACENA-UNNE, Consejo Nacional de Investigaciones Científicas y Ténicas/CONICET, Av. Libertad 5470, Corrientes, Argentina \\ ${ }^{2}$ Chelonia Argentina, Virasoro 2804, 3400, Corrientes, Argentina \\ ${ }^{3}$ Chelonia Romania, Pascani5, sector 6, Bucharest 062082, Romania \\ ${ }^{4}$ Fundación Amado Bompland, San Juan 1182, Corrientes 3400, Argentina \\ ${ }^{5}$ Faculty of Natural and Agricultural Sciences, Ovidius University Constanta, A1. \\ Universitatii 1, Campus B, lab P43, Constanta 900470, Romania
}

Manuscript received on May 23, 2018; accepted for publication on August 25, 2018

\begin{abstract}
How to cite: MARANGONI F, COURTIS A, PIÑEIRO JM, INGARAMO MDR, CAJADE R AND STĂNESCU F. 2019. Contrasting life-histories in two syntopic amphibians of the Leptodactylus fuscus group (Heyer 1978). An Acad Bras Cienc 91: e20180507. DOI. 10.1590/0001-3675201920180507.
\end{abstract}

\begin{abstract}
We used skeletochronology to compare age, size, reproductive parameters and growth patterns of two related, anuran amphibians from Northern Argentina: Leptodactylus bufonius ( $\mathrm{n}=69$ ) and L. latinasus $(\mathrm{n}=56)$, in order to better understand their coexistence in syntopy. Previous studies showed that the two species overlap in their dietary requirements and utilize the same habitats for feeding and breeding. We found that their life-history patterns are significantly different, L. bufonius being larger, and having a higher reproductive output and lifespan, compared to the smaller and shorter-living L. latinasus. Since none of the species exhibited sexual size dimorphism, and both acquired sexual maturity after the first year of life, we suggest that the differences in the observed life-history parameters must appear during early stages of development, during larval and/or juvenile stages.
\end{abstract}

Key words: age, Anura, body size, growth, Leptodactylus bufonius, Leptodactylus latinansus.

\section{INTRODUCTION}

Body size, growth and lifespan are central life history traits related to fitness, and ultimately to reproductive success and survival (Calder 1984, Schmidt-Nielsen 1984, Brown et al. 1993, Stearns 2000, Metcalfe and Monaghan 2003), which makes the study of intra- and interspecific variation in these traits an essential goal for understanding life-

Correspondence to: Federico Marangoni

E-mail: fedemarangoni@gmail.com

ORCid: https: //orcid.org/0000-0001-6242-9222 history evolution. In amphibians, several factors may contribute to the variation in adult body size, either within species or among them. Traditionally, it has been considered that variation in body size can simply reflect an underlying pattern of variation in the age structure of populations (DíazPaniagua and Mateo 1999, Miaud et al. 1999, Laugen et al. 2005). Variations in juvenile growth rates to sexual maturity and age at maturity may promote divergences in adult body size between species and populations or sexual size dimorphism within a population (Hemelaar 1985, Monnet and 
Cherry 2002). Thus, an important factor in the analysis of variation of body size in amphibians is the indeterminate growth pattern that they exhibit, which becomes asymptotic when sexual maturity is reached (Halliday and Verrel 1988). Fast growth and early sexual maturity is one of the life strategies that determines increased efficacy at the expense of reaching a smaller adult size (Roff 1993, Stearns 1992). In contrast, the benefits of delaying reproduction are generally related to the benefits associated with large body size, which is positively related to fecundity and breeding success (Howard 1980, Berven 1981), jumping performance (Tejedo et al. 2000) and competition (Tejedo 1988). Large body size is also associated with higher survivorship and clutch size (Berven 1982a, Gibbons and McCarthy 1986, Begon et al. 1990, Stearns 1992). In addition, the environmental conditions experienced by the mother (non-genetic factors), are an important determinant of offspring adult body size, due to the maternally induced variation in egg size (Kaplan 1998). For example, a smaller egg size may determine a smaller size at metamorphosis (Bernardo 1996) and, when compensatory growth does not take place (Metcalfe and Monaghan 2003, Hector and Nakagawa 2012), it can determine small adult body size (Bernardo 1996, Räsänenetal et al. 2003, 2005, Laugen et al. 2005, Marangoni 2006).

Skeletochronology is a useful technique to estimate individual age in amphibians, and discriminate variations in growth rates and agerelated parameters such as age and size at sexual maturity, longevity, and potential reproductive lifespan (Sinsch 2015). These life-history parameters also allow explaining the actual pattern of sexual size dimorphism in amphibians (Marangoni et al. 2012, Cajade et al. 2013, Quiroga et al. 2015). Skeletochronology is based on the presence of cyclic and annular bone growth, which can be visualized in cross-sections of bones (Castanet 1982, Castanet and Smirina 1990). This method is commonly and successfully used for evaluating the age of many species of amphibians and reptiles, providing an age estimate through non-lethal means (Castanet and Smirina 1990, Marangoni et al. 2009, 2012, Sinsch 2015).

The comparative study of life-history traits in related amphibian species which undergo similar environmental conditions is a good way to understand interspecific interactions and explain how differences in life-history strategies allow the coexistence of these species (MacArthur and Levin 1967, MacArthur 1970, Pianka 1975, Toft 1980, 1981). We used skeletochronology to compare the life-history patterns of two closely-related species of the Leptodactylus fuscus group (Heyer 1978), which occupy the same habitats in the wet Chaco region of northern Argentina. Specifically, we estimated and compared body size, age, growth and reproductive parameters for the two species, aiming to explain the life-history strategies that allow their coexistence.

\section{MATERIALS AND METHODS}

\section{STUDY SPECIES}

The monophyletic genus Leptodactylus (Fitzinger 1826) has a predominantly Neotropical distribution and is composed of 75 currently recognized species included in four groups: Leptodactylus fuscus (30 species), L. melanonotus (17 species), L. latrans (8 species), L. pentadactylus (17 species) and three species unassigned to any species group (De Sá et al. 2014). The study species, Leptodactylus latinasus (Jiménez de la Espada 1875) and L. bufonius (Boulenger 1894), belong to the monophyletic $L$. fuscus clade (De Sá et al. 2014). Leptodactylus latinasus is distributed in Argentina (Vaira et al. 2012), Bolivia, Paraguay, south and east throughout Uruguay and southern Brazil (Lavilla et al. 2004). Leptodactylus bufonius is distributed in Argentina (Cabrera and Willink 1980, Carnevali 1994, Vaira et al. 2012), southern Bolivia, Paraguay, and central 
Brazil (Heyer 1978). The two species are common, and sharing habitats scattered throughout the Chaco and Espinal ecoregions (Cabrera and Willink 1980, Carnevali 1994, Vaira et al. 2012). Males of both species construct mud nests at the edge of ponds and other low-lying depressions, and call near semi-permanent or ephemeral water bodies, from inside or close to the chambers (Heyer 1978, Cei 1980, Faggioni et al. 2017). The two species share the same reproductive mode (Duellman and Trueb1986) and their trophic niche overlaps to a great extent (Duré and Kehr 2004).

\section{STUDY SITE}

Fieldwork was carried out in the area called "El Perichón" (2725'53.1" S, 5844'44.8” W), 10 km northeast from Corrientes city, Argentina, where L. latinasus and L. bufonius live in syntopy. This area is characterized by the presence of numerous temporary and semi-permanent ponds. Mean annual temperature is $21.5^{\circ} \mathrm{C}$ and the mean annual precipitation is $1500 \mathrm{~mm}$, without a pronounced dry season, although periods of rain shortages occur every 4-6 years (Carnevali 1994). The original vegetation was Schinopsis balansae "quebracho" forest, which is currently extremely degraded and largely replaced by sclerophyllous forest, with prevalence of Acacia caven, Celtis spp., Prosopis affinis, Prosopis nigra, and numerous colonies of Aechmea distichantha and Bromelia spp. (Carnevali 1994). Eight out of thirteen species of Leptodactylus genus reported for Argentina are present in the study area: five belong to L. fuscus group (L. bufonius, L. elenae, L. gracilis, L. latinasus, and L. mystacinus), two to the L. latrans group (L. latrans and L. chaquensis) and one to the L. melanonotus group (L. podicipinus).

SAMPLING

We sampled 56 L. latinasus (34 males, 17 females and five juveniles), and 69 L. bufonius (56 males, 9 females and four juveniles), from autumn 2007 to late spring 2008. The frogs were captured between 20:00 and 23:00 h. The sampling followed the ethical standards imposed by the Dirección de Recursos Naturales of the Corrientes province, Argentina. Most males (26) were captured by hand when they were calling on the ground away from ponds, hidden in crevices (L. latinasus) or near the cone-shaped nests (L. bufonius). Remaining males and females were collected during migration or at the edge of the breeding ponds. In these cases, sex and sexual maturity was determined by the presence of dark vocal sac (males), or ova that could be visualized through the skin (females). Frogs were separated by sex, placed in independent plastic containers (12 cm diameter x $6.5 \mathrm{~cm}$ height), and brought to the laboratory.

We measured snout-vent length (SVL) and right hind-limb length (HL) by placing each frog on laminated graph paper (accuracy $\pm 1 \mathrm{~mm}$ ). We measured the head width (HW), arm length (AL) and tibia length (TL) to the nearest $0.1 \mathrm{~mm}$ with digital calipers. We measured body mass $(\mathrm{BM})$ to the nearest $0.01 \mathrm{~g}$, using an Acculab electronic balance (Acculab Scales, Titusville, $\mathrm{NJ}$ ). In addition, we measured 67 specimens of related Leptodactylus species from the Collection of Laboratorio de Genética Evolutiva (Instituto de Biología Subtropical (CONICET-UNaM), Posadas, Misiones, Argentina), which we considered useful for further comparisons: 13 Leptodactylus furnarius, 18 L. laticeps and 36 L. plaumanni (Appendix A, B). All measurements were taken according to Duellman (1970).

Most individuals (109 out of $125 ; 87 \%$ ) were released back into their original ponds within 24-48 h after their capture. Ten L. latinasus and six L. bufonius females were preserved for the analysis of reproductive traits, and further genetics and morphological studies, and deposited in the Collection of Laboratorio de Genética Evolutiva, Instituto de Biología Subtropical (CONICET- 
UNaM), Posadas, Misiones, Argentina (see Appendix A for specimen codes).

\section{SEXUAL SIZE DIMORPHISM}

We checked for significant differences in size parameters (i.e. SVL, BM, HW, AM and TL) between sexes, using multi- and univariate analyses of variance (with type III Sum of Squares). We used Pearson correlation coefficient adjusted for small sample sizes (radj) to analyze the associations between these parameters.

We assessed the sexual size dimorphism (SSD) for each body measurement using the sexual dimorphism index (SDI), following Lovich and Gibbons (1992): SDI = mean size larger sex $/$ mean size $_{\text {smaller sex }}$, with the result arbitrarily defined as positive when females are larger than males, and negative when males are larger.

\section{SKELETOCHRONOLOGY}

We clipped the third toe of the right leg of $28 \mathrm{~L}$. latinasus (12 males, 12 females, four juveniles) and 35 L. bufonius (24 males, 7 females, four juveniles) (Table II), and stored them in 70\% ethanol at room temperature for age estimation through skeletochronology. We followed the standard protocols used in skeletochronology (e.g. Smirina 1972). We selected the third phalanx of the toe, which was washed in water for 30 min, and decalcified in 5\% nitric acid for 30-45 min. Afterwards, the samples were washed in running tap water for $5 \mathrm{~min}$ and kept overnight in distilled water. Then, the phalanges were frozen (Tissue-Tek O.C.T. Compound, Sakura Finetek) and cross-sectioned at $16 \mu \mathrm{m}$ using a cryo-microtome. Sections were stained for 3-6 h at room temperature with Ehrlich's hematoxylin (Tejedo et al. 1997). 15 to 20 of these sections were permanently mounted in aqueous synthetic resin (Aquatex ${ }^{\circledR}$, Merck KgaA, Germany) on glass microscope slides. Cross sections were examined light microscopically at magnifications of 20x using a Nikon Optiphot microscope. A Canon PowerShot A570 was used to take digital images from those diaphysis sections in which the size of the medullar cavity was at its minimum and that of periosteal bone at its maximum. Cross sections were viewed and measured using the computer package Image-Pro Plus Version 1.1 (Media Cybernetics 1993-1994). In a first step of the analysis, we recorded the presence/absence of the line of metamorphosis (LM) and of lines of arrested growth (LAGs). The number of LAGs visible in each cross section was assessed by FM and independently by AC. In those frogs with no remnant of the line of metamorphosis we estimated the degree of resorption by osteometrical analysis, following the method of Sagor et al. (1998). In a second step, we distinguished annual growth marks (LAGs sensu stricto) from non-annual ones (irregular interruptions of the aestivation periods), following Sinsch et al. (2007). The age of maturity was defined as the lowest age recorded in a reproductive frog of a given population.

\section{AGE-RELATED PARAMETERS}

We computed the following age-related parameters (sensu Leskovar et al. 2006): (1) age at maturity: the minimum number of LAGs counted in breeding individuals; (2) longevity: the maximum number of LAGs counted in breeding individuals; (3) potential reproductive lifespan: the difference between longevity and age at maturity; (4) mean lifespan; (5) size at maturity: the average snout-vent length of all individuals with the minimum number of LAGs. We used a two-sample Kolmogorov-Smirnov and Mann-Whitney test to check for differences in the shape of age distribution and median age between males and females. We used linear regressions to analyze the associations between age and body size parameters. 


\section{GROWTH PATTERNS}

We used the packages FSA (Ogle 2018) and nlstools (Baty et al. 2015) in R Studio version 1.1.423 (C 2009-2018 RStudio, Inc.) to compute von Bertalanffy's growth model (Bertalanffy 1938) following Beverton and Holt (1957): SVLt $=$ SVLmax $x\left(1-e^{-k x(t-t)}\right)$, where SVLt is the expected or average SVL at time (or age) $t$, SVLmax is the asymptotic average SVL, $\mathrm{k}$ is the growth rate coefficient and $t_{0}$ is the time or age when the average SVL was zero. We fitted von Bertalanffy growth model and estimated growth parameters (VBGPs) by nonlinear least squares regression. Two estimated VBGPs were considered significantly different at the 0.95 level when their confidence intervals (CI 95\%) did not overlap. We used the value of $10.9 \mathrm{~mm}$ as the mean size at metamorphosis (0 LAGs) found in L. bufonius by Vera and Ponssa (2014), to adjust the growth model, since no freshly metamorphosed individuals could be captured from the studied area. Based on the known life-history patterns of the species (i.e. breeding period and larval development) and the moment of sampling, we assigned the age of 0.25 LAGs to L. bufonius and L. latinasus juveniles, assuming that only 3 months elapsed since their metamorphosis.

\section{REPRODUCTIVE TRAITS}

Reproductive traits were measured in 16 females: ten L. latinasus and six L. bufonius. We determined the ovarian mass (OM) as the difference between the body mass before and after ovary removal. The ovarian complement (OC) represents the total number of mature ova from each gravid female and is considered a measure of their fertility or reproductive potential (Crump 1974, Basso 1990). We removed and weighed approximately 10\% of each ovary and counted the mature ova under a Nikon C-DS magnifying glass. Mature ova had well-definedblack and yellow poles and pronounced larger size, consistent with the post-vitellogenesis class (Crump 1974). We photographed a random sample of about 200 ova from each ovary with a digital Nikon Coolpix S10 camera, mounted on a Nikon C-DS magnifying glass. We measured the longest and shortest perpendicular axes of 100 ova per sample to the nearest $0.01 \mathrm{~mm}$ using ImagePro Plus 1.1 (Media Cybernetics 1993-94). We determined mature ovum size (OS) by square rooting the product of the two axis measurements. We estimated the ovarian size factor (OSF) which correlates the number and size of mature ova to body length, following Duellman and Crump (1974): OSF $=($ OC x OS $) / S V L$. Finally, we estimated the reproductive effort (RE) following Prado et al. (2000): $\mathrm{RE}=(\mathrm{OM} / \mathrm{BM}) \times 100$, where the body mass is the final weight of the female after oviposition. We used Pearson product-moment correlation coefficient adjusted for small sample sizes $\left(\mathrm{r}_{\text {adj }}\right)$ to analyze the associations between size and reproductive parameters.

\section{STATISTICAL ANALYSIS}

Body size variables were log-transformed in order to achieve normality. We tested all data for normality and homoscedasticity using ShapiroWilk and Levene tests and chose the statistic tests accordingly. We used multi- and univariate analyses of variance to test for differences in body size between the sexes. We used linear regressions to test the association between body size, age and clutch characteristics. All statistical analyses were performed using STATISTICA 6.0 package (StatSoft Inc. 2001).

\section{RESULTS}

\section{BODY SIZE AND SEXUAL SIZE DIMORPHISM}

Both species (Table I) showed no significant effect on all measured morphometric variables ( $L$. latinasus: Wilk's $\lambda=0.771, F_{6,39}=1.920, P=0.101 ; L$. bufonius: Wilk's $\lambda=0.846, F_{6,58}=1.750, P=0.125$ ). 


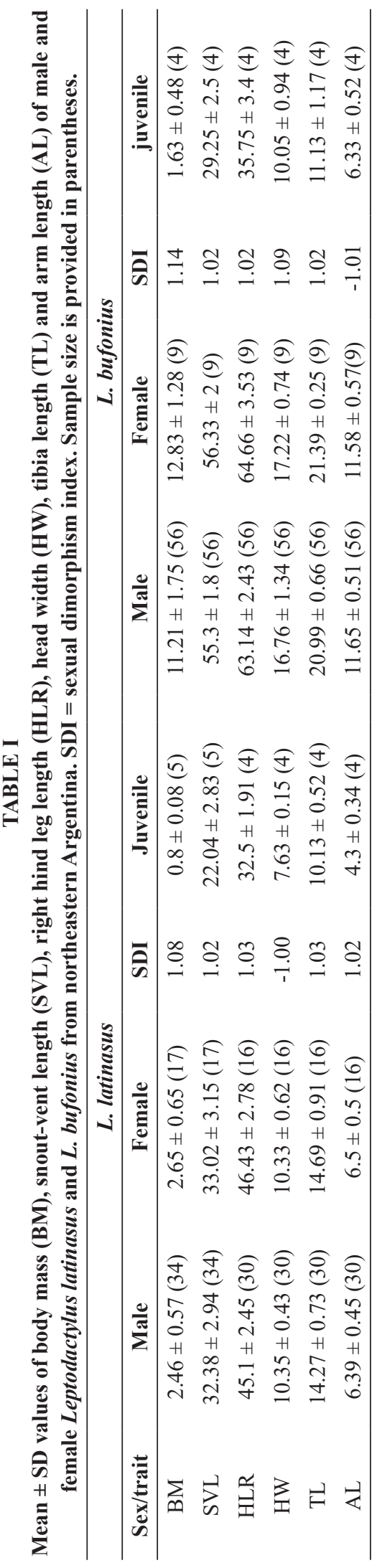

The values of sexual dimorphism index (SDI) were negative for head width (-1.00) in L. latinasus and arm length (-1.01) in L. bufonius, showing that the males were larger than females in these variables, whereas the females were larger than males in the remaining variables studied (Table I). We found a positive and significant correlation between body mass and SVL in both species. This correlation showed differences in the slope between the two species, with body mass increasing faster with SVL in L. bufonius compared to L. latinasus (Fig. 1).

\section{AGE-RELATED PARAMETERS}

All sections showed recognizable bone structures that allowed age determination. We found welldefined LAGs in the periosteal bone of these sections, and they were relatively easy to count in order to assess individual age (Fig. 2). The descriptive statistics of the studied life historytraits are summarized in Table II, and the age structure is presented in Fig. 3. The minimum number of LAGs found in reproductive individuals was one in both species. One-year old L. latinasus males were on average smaller than one-year old females, whereas in L. bufonius males were bigger than females within the one-year old age class. On average, males were older than females in both species; however, the differences in the median lifespan between sexes were significant only in $L$. latinasus (Mann-Whitney $U$ test, $\mathrm{Z}=2.849, P=$ $0.004)$. Longevity in L. latinasus was three years in males and two years in females, while females were older in L. bufonius (five years in females and four years in males). Thus, the difference in the potential reproductive lifespan (PRLS) between sexes was one year in both species. We found no LAGs in the cross sections of juveniles.

\section{GROWTH PATTERNS}

Since MANOVA on all morphometric variables measured showed no significant effects of sex 

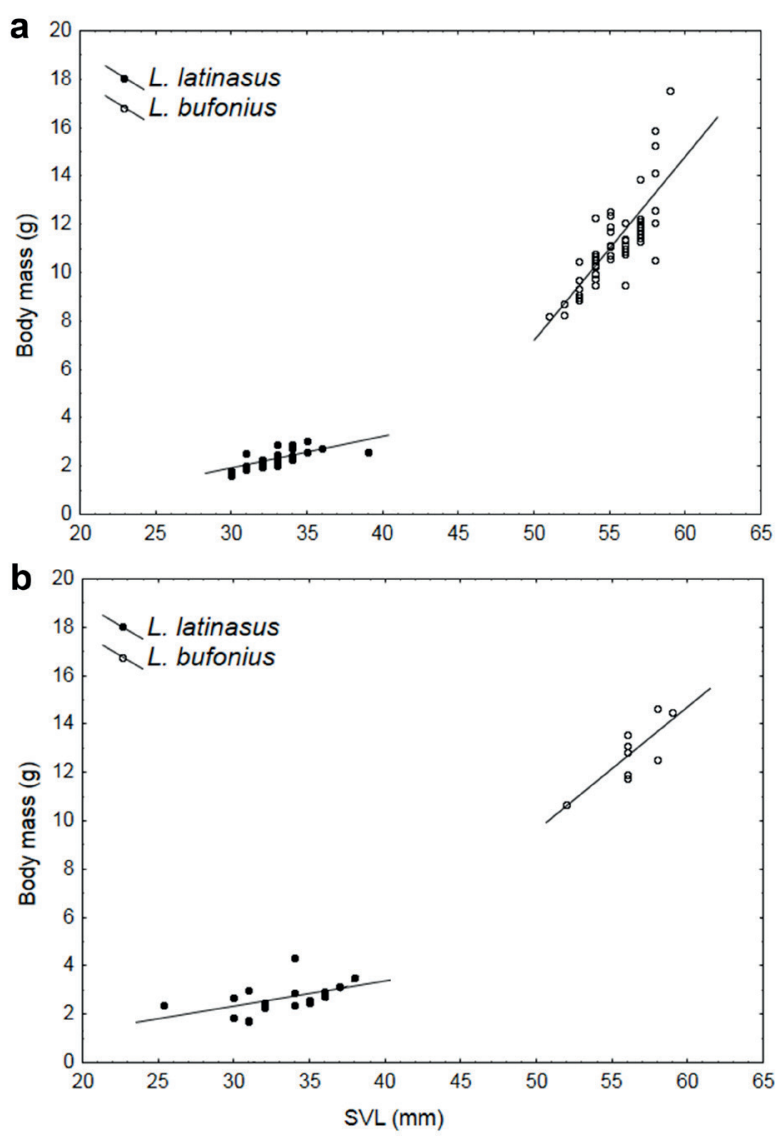

Figure 1 - Snout-vent length (SVL) and body mass (BM) relationships in Leptodactylus latinasus and L. bufonius males (a) and females (b).

in both species, we computed Von Bertalanffy's growth model using pooled data of males and females (Fig. 4). The asymptotic average snoutvent length was significantly higher in L. bufonius $(\mathrm{SVLmax} \pm \mathrm{SE}=56.22 \pm 0.43$, CI $95 \%=55.35$ $-57.09, \mathrm{~K} \pm \mathrm{SE}=3.62 \pm 0.44$, CI $95 \%=2.71-$ 4.52) than in L. latinasus (SVLmax $\pm \mathrm{SE}=32.68$ \pm 0.816 , CI $95 \%=31.00-34.36, \mathrm{~K} \pm \mathrm{SE}=2.60$ \pm 0.55 , CI $95 \%=1.46-3.75)$. Although we found no significant differences in the growth coefficient, the growth rates during the first year of life, from metamorphosis to sexual maturity, appear to be distinct in the two species: L. latinasus had a mean SVL of only $32.6 \mathrm{~mm} \mathrm{(n=12} \mathrm{one-year} \mathrm{old}$ individuals: four males, eight females), compared to L. bufonius which attained a mean SVL of $56.8 \mathrm{~mm}$ in the same age class ( $\mathrm{n}=8$ one-year old individuals: four males, four females). In addition, there were significant differences both in the size and age distribution of the two species, L. bufonius being larger (Mann-Whitney U-test, $U=50, P<0.001$ ) and having a higher average lifespan compared to $L$. latinasus (M-W, $U=257, P=0.006)$.

\section{REPRODUCTIVE TRAITS VS FEMALES' SIZE}

The descriptive statistics of the reproductive variables in both species are presented in Table III. Following the differences in body size between species, all reproductive traits were higher in L. bufonius than L. latinasus. However, the relationships among reproductive variables (i.e. ovarian complement, ovarian mass and ovum size), female size (i.e. snout-vent length, body mass) and age in L .latinasus and L. bufonius were statistically non-significant (Table IV). In L. latinasus, the mean OC increased with SVL, BM and age. Similarly, OM increased with BM and age, but the relationship with SVL was negative. OS increased with age, but decreased with SVL and BM. On the other hand, in L. bufonius, OC increased with age, but showed a negative relationship with SVL and BM. Moreover, OM showed a positive relationship with SVL and age, but had a negative relationship with BM. Finally, OS increased significantly with SVL, BM and age.

\section{DISCUSSION}

\section{INTRASPECIFIC DIFFERENCES IN BODY SIZE AND AGE-RELATED PARAMETERS}

Several non-mutually exclusive factors may contribute to SSD in amphibians, such as environmental conditions, phylogeny, genetic drift, or natural and sexual selection (Berven 1982a, b, Marangoni and Tejedo 2008, Cogălniceanu et al. 2014). In most anurans, females are larger than males and in overall this is explained by the positive correlation between female body size and 

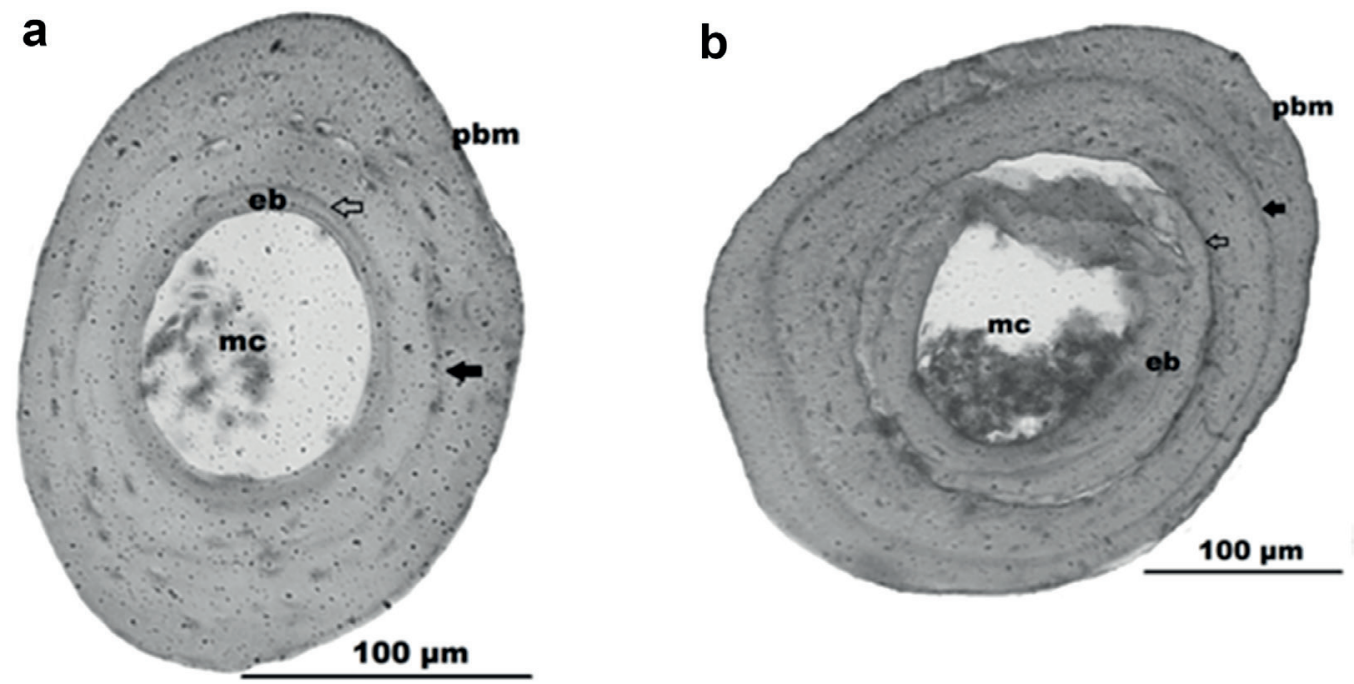

Figure 2 - Cross sections through a phalanx of Leptodactylus latinasus (a) and L. bufonius (b). An arrowhead indicates the lines of arrested growth (LAGs), medullar cavity (mc), endosteal bone (eb), periosteal bone margin (pbm).

reproductive output (Shine 1979, Duellman and Trueb 1986). However, in some cases males are larger than females or there is no SSD (Shine 1979, Silva et al. 2005, Zina and Haddad 2005). We did not find a significant SSD in the studied L. latinasus and $L$. bufonius populations, in any of the analyzed morphological variables. However, a femalebiased SSD was reported in other populations of L. bufonius (Heyer 1978, Reading and Jofré 2003, Schaefer 2007, Faggioni et al. 2017, but see Duré and Kehr 2004) and L. latinasus (Heyer 1978, Duré and Kehr 2004, Schaefer 2007, Ponssa and Barrionuevo 2012, Attademo et al. 2014), and likewise, in the other 11 species of the genus distributed in Argentina (Appendix B). Regarding species of the Leptodactylus fuscus group, where males construct subterranean chambers, Heyer (1978) hypothesized a relationship between burrowing habits and sexual dimorphism, males having larger heads compared to females (Faggioni et al. 2017). We found no SSD in the head width of either species studied, but our results are similar to those obtained by Ponssa and Barrionuevo (2012).
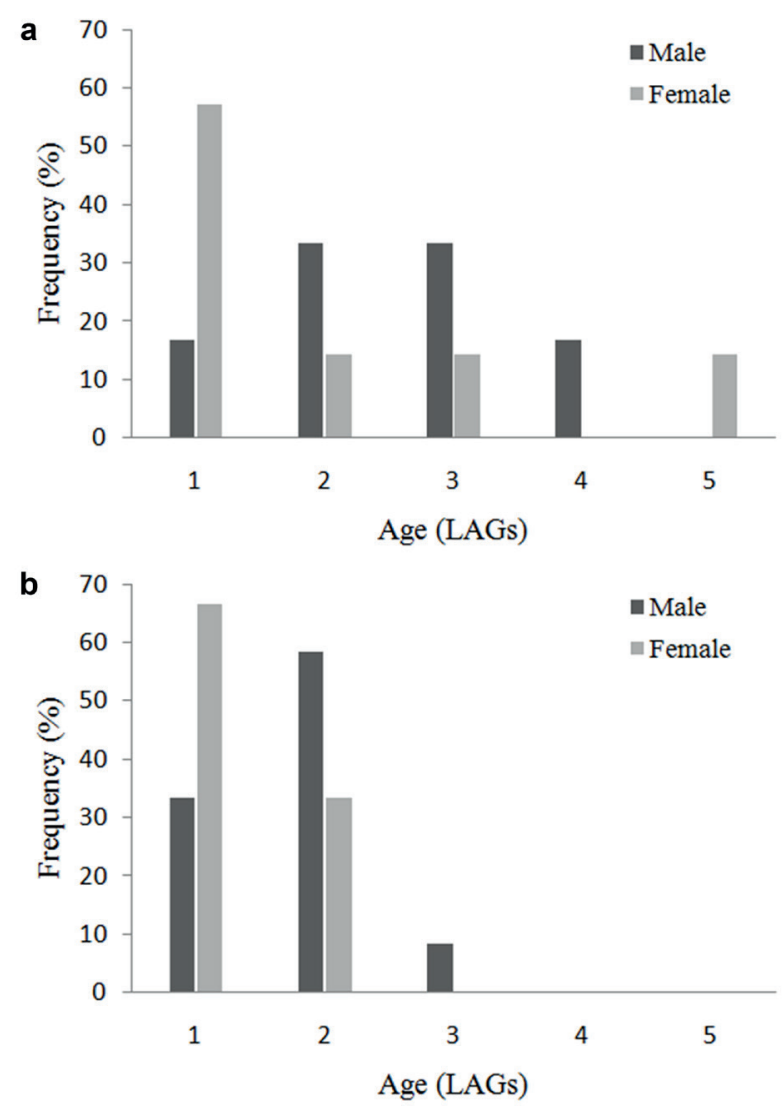

Figure 3 - Population age structure in males and females of $L$. bufonius (a) and L. latinasus (b). 
TABLE II

Age-related traits of Leptodactylus latinasus and L. bufonius. AM = age at maturity (i.e. the minimum age in the sample, in LAGs); Longevity = maximum age in the sample (LAGs); PRLS = potential reproductive lifespan (years); Mean and maximum size at $\mathrm{AM}=$ mean and maximum snout-vent length of first-year breeders $(\mathrm{mm})$. Sample size is provided in parentheses.

\begin{tabular}{ccccccccc}
\hline Species/Sex & $\begin{array}{c}\text { Mean age } \\
\pm \text { SE }\end{array}$ & $\begin{array}{c}\text { Modal } \\
\text { age }\end{array}$ & $\begin{array}{c}\text { Median } \\
\text { age }\end{array}$ & AM & Longevity & PRLS & $\begin{array}{c}\text { Mean size at } \\
\text { AM } \pm \text { SD }\end{array}$ & $\begin{array}{c}\text { Maximum } \\
\text { size at AM }\end{array}$ \\
\hline $\begin{array}{c}\text { L. } \text { latinasus } \\
\text { Males (12) }\end{array}$ & $1.75 \pm 0.62$ & $2(7)$ & 2 & 1 & 3 & 2 & $31.27 \pm 5.15(4)$ & $39(1)$ \\
Females (12) & $1.33 \pm 0.49$ & $1(8)$ & 1 & 1 & 2 & 1 & $32.43 \pm 3.51(8)$ & $38(2)$ \\
\hline L. bufonius & & & & & & & & 5 \\
Males (24) & $2.5 \pm 0.98$ & $2-3(8)$ & 2.5 & 1 & 4 & $57.25 \pm 1.7(4)$ & $59(1)$ \\
Females (7) & $2.0 \pm 1.52$ & $1(4)$ & 1 & 1 & 5 & 4 & $56.5 \pm 1.0(4)$ & $59(5)$ \\
\hline
\end{tabular}

Several species of Leptodactylus exhibit male combat, a main source that have been widely proposed to explain the existence of sexual size dimorphism in anurans (Shine 1979, Blanckenhorn 2000, Monnet and Cherry 2002), but although we observed male-male interaction in L. bufonius, with the consequent emission of territorial calls (F. Marangoni, personal observation), we never observed male combat in either of the two species studied (F. Marangoni, personal observation). Thus, we suggest that the absence of male combat could be another possible explanation for the absence of sexual size dimorphism in these species.

Variation in age structure promoting considerable variation in adult body size has been widely demonstrated in amphibians (Díaz-Paniagua and Mateo 1999, Miaud et al. 1999, Laugen et al . 2005, Marangoni et al. 2006, 2012, Cajade et al. 2013, Quiroga et al. 2015, Sinsch et al. 2015). In addition, contrasting life-strategies related to growth rates, age and body size at sexual maturity of males versus females can also shape sexual size dimorphism in amphibians (Hemelaar 1988, Halliday and Tejedo 1995). We found that sexual maturity was reached after the first year of life in males and females of both species studied, which could also explain the absence of a significant sexual size dimorphism. Basso and Kehr (1991)

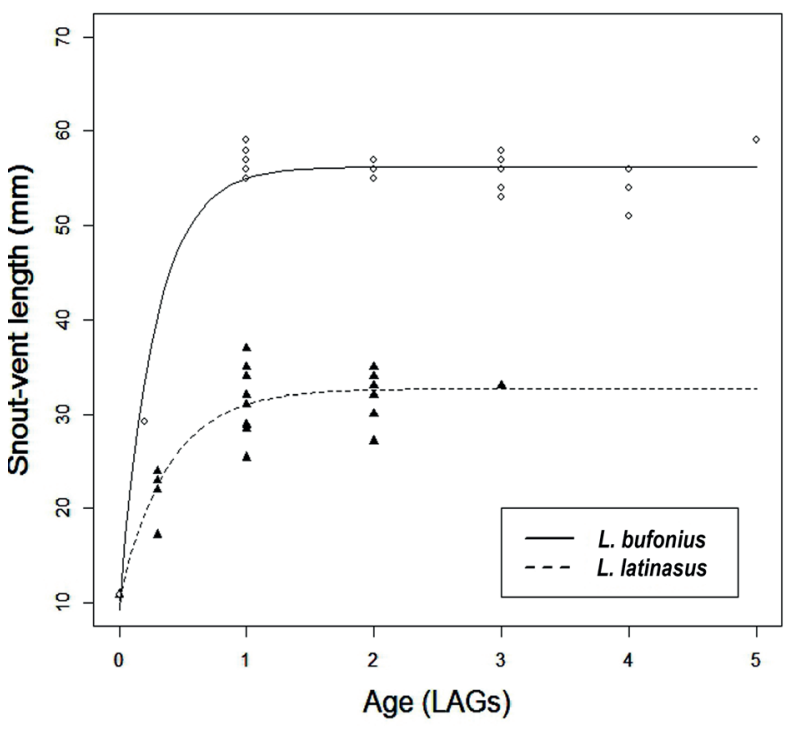

Figure 4 - Growth patterns in Leptodactylus latinasus (black triangles) and L. bufonius (open circles).

also found that L. latinasus attains sexual maturity after the first year of life. Similar age at maturity and longevity (one and five years, respectively) and no SDD was also found in a related species L. latrans, by López et al. (2017) and the authors proposed that the lack of SSD is probably due to the lack of differences in the age structure of males and females, females having only a slightly delayed sexual maturity. In contrast, other studies found that males and females attained sexual maturity after the second year of life in L. bufonius (Reading and 
TABLE III

Reproductive traits of Leptodactylus latinasus and $L$. bufonius females. SVL = snout-vent length; OM = ovarian mass; $\mathrm{OC}=$ ovarian complement; $\mathrm{OS}=$ ovum size; $\mathrm{RE}=$ reproductive effort; $\mathrm{OSF}=$ ovarian size factor. Values are presented as Mean \pm SD. Sample size is provided in parentheses.

\begin{tabular}{ccccccc}
\hline Species & SVL $(\mathbf{m m})$ & OM $(\mathbf{g})$ & OC & OS $(\mathbf{m m})$ & RE $(\%)$ & OSF \\
\hline L. latinasus & $33.03 \pm 3.16(17)$ & $0.20 \pm 0.10(10)$ & $224.30 \pm 51.43(10)$ & $1.19 \pm 0.14(10)$ & $6.44 \pm 2.97(10)$ & $7.95 \pm 2.26(10)$ \\
L. bufonius & $56.33 \pm 2.00(9)$ & $1.73 \pm 1.54(6)$ & $400.17 \pm 117.89(6)$ & $1.29 \pm 0.17(6)$ & $17.11 \pm 16.54(6)$ & $9.33 \pm 2.91(6)$ \\
\hline
\end{tabular}

TABLE IV

Relationship between reproductive variables (i.e. ovarian complement, ovarian mass, ovum size), body size (snout-vent length, body mass) and age in Leptodactylus latinasus and $L$. bufonius females. All variables were log-transformed. All relationships were statistically not significant.

\begin{tabular}{|c|c|c|c|c|c|c|}
\hline \multirow{2}{*}{$\begin{array}{l}\text { Reproductive traits (y) vs. } \\
\text { body size }\end{array}$} & \multicolumn{3}{|c|}{ Leptodactylus latinasus } & \multicolumn{3}{|c|}{ Leptodactylus bufonius } \\
\hline & n & Equation & $\mathbf{r}^{2}$ & $\mathbf{n}$ & Equation & $\mathbf{r}^{2}$ \\
\hline \multicolumn{7}{|l|}{ Ovarian Comp. } \\
\hline SVL & 10 & $y=-0.8606+1.767 x$ & 0.2703 & 6 & $y=14.4744-2.1199 x$ & 0.0635 \\
\hline $\mathrm{BM}$ & 10 & $y=-0.313+0.2303 x$ & 0.0968 & 6 & $y=7.7499-0.5038 x$ & 0.2628 \\
\hline Age & 7 & $y=5.3276+0.0573 x$ & 0.0059 & 5 & $y=5.9463+0.0833 x$ & 0.0147 \\
\hline \multicolumn{7}{|l|}{ Ovarian mass } \\
\hline SVL & 10 & $y=0.3483-0.0793 x$ & 0.0323 & 6 & $y=-16.9517+4.3615 x$ & 0.0932 \\
\hline $\mathrm{BM}$ & 10 & $y=0.7944+1.9593 x$ & 0.1179 & 6 & $y=5.0727-1.2619 x$ & 0.5721 \\
\hline Age & 7 & $y=0.271+0.3624 x$ & 0.0013 & 5 & $y=0.5017+0.7775 x$ & 0.5597 \\
\hline \multicolumn{7}{|l|}{ Ovum size } \\
\hline SVL & 10 & $y=2.7067-0.7174 x$ & 0.1791 & 6 & $y=-10.9025+2.7752 x$ & 0.4827 \\
\hline $\mathrm{BM}$ & 10 & $y=0.2494-0.0855 x$ & 0.0161 & 6 & $y=0.0279+0.0625 x$ & 0.0179 \\
\hline Age & 7 & $\mathrm{y}=0.1725+0.0579 \mathrm{x}$ & 0.0253 & 5 & $\mathrm{y}=0.29+0.054 \mathrm{x}$ & 0.1160 \\
\hline
\end{tabular}

Jofré 2003) and L. latinasus (Attademo et al. 2014). Attademo et al. (2014) found that age at maturity and longevity where 3 and 7 years respectively, in L. mystacinus.

\section{INTERSPECIFIC DIFFERENCES IN LIFE-HISTORY TRAITS}

The observed differences in adult body size paralleled the differences in age-related parameters (longevity and PRLS), all reproductive traits, and growth pattern in both species. Observed SVL of first-breeders suggest that distinct growth patterns occur before sexual maturity in the two species, $L$. bufonius achieving a larger body size compared to L. latinasus, during the same amount of time. This pattern is also evident from the SVL-BM relationship, body mass increasing faster with SVL in L. bufonius compared to L. latinasus (Fig. 1). Overall, L. bufonius is larger than L. latinasus, and females have a higher reproductive investment. In addition, the potential reproductive lifespan (PRLS) is also higher in L. bufonius, which increases the potential reproductive success of the species (Halliday and Verrel 1988, Halliday and Tejedo 1995, Blanckenhorn 2000). Overall, our study indicates that L. bufonius exhibits a more successful life-history strategy and therefore has better chances to displace L. latinasus in competition for resources. However, Duré and Kehr (2004) showed that L. latinasus and $L$. bufonius exhibit niche complementarity, which means that under satisfactory levels of food and 
space availability, competition should not be an issue, and thus explaining the coexistence of the two species in syntopy. Furthermore, competition is avoided through spatial segregation between $L$. latinasus and L. bufonius: for example, although males of both species construct mud nests at the edge of ponds and other low-lying depressions (Heyer 1978, Cei 1980), there are subtle differences in their microhabitat preferences and reproductive behavior (see Crump 1995), L. latinasus being usually associated to crevices in the ground, while L. bufonius constructs cone-shaped nests at the edge of the ponds (Shoemaker and McClanahan 1973, Crump 1995, F. Marangoni, personal observation during present study). Since both species use the same ponds for breeding, at the same time, interspecific interaction is most likely to occur during larval stages. However, little is known regarding the length of larval development, dietary requirements, foraging behavior of the tadpoles, or size at metamorphosis. Hence, studies regarding growth, diet and foraging behavior during earlystages of life in both species are required to fully understand the mechanisms that shape their lifehistories and allow their coexistence.

\section{ACKNOWLEDGMENTS}

We are grateful to V. I. Gomez for invaluable help during fieldwork. We acknowledge L. Rossi and A. Ibañez for their assistance in the sample processing. We acknowledge M. Sanchez-Negrette and M. Montenegro for providing the corresponding permits to use the cryostat microtome at the Cátedra de Patología General y Sistemática and Cátedra de Histología y Embriología, Facultad de Ciencias Veterinarias, Universidad Nacional del Nordeste. We thank D. Baldo for acces to the database of amphibian collections of the Laboratorio de Genética Evolutiva del Instituto de Biología Subtropical (CONICET-UNaM). We thank J. J. Neiff for providing the Microscopy
Laboratory at the Centro de Ecología Aplicada del Litoral (CECOAL, CONICET // UNNE). We thank also H. Duarte, a native speaker, for correcting the English draft of this manuscript. D. Cogălniceanu reviewed earlier versions of the manuscript and provided useful comments that helped improve it. The authors have complied with all applicable Institutional Animal Careguide lines. The collecting permit was granted by Dirección de Recursos Naturales of the Corrientes province, Argentina. This project was supported by Consejo Nacional de Investigaciones Científicas y Técnicas (CONICET), Argentina, through fellowships to F. Marangoni. We are very grateful for the continuous support of the CONICET and the Facultad de Ciencias Exactas y Naturales y Agrimensura, Universidad Nacional del Nordeste (FACENA, UNNE).

\section{AUTHOR CONTRIBUTIONS}

FM, JMP, MRI, RC performed the fieldwork. $\mathrm{FM}$ and $\mathrm{AC}$ performed the laboratory analyses. AC performed the literature review. FM and FS performed the statistical analyses and wrote the manuscript. JMP, MRI and RC prepared the tables and figures; all authors critically revised the manuscript and approved the final version.

\section{REFERENCES}

ATTADEMO MA, BIONDA C. PELTZER PM, LAJMANOVICH RC, SEIB SN, BASSO AAND JUNGES CM. 2014. Age, size at sexual maturity, longevity, and reproductive potential of Leptodactylus latinasus and Leptodactylus mystacinus in a soybean crop and a native forest from mideastern Argentina. Rev Mex Biodivers 85: 315-317.

BASSO NG. 1990. Estrategias adaptativas en una comunidad subtropical de anuros. Cuad Herpetol (AHA) 1: 1-71.

BASSO NG AND KEHR AI. 1991. Postmetamorphic growth and population structure of the frog Leptodactylus latinasus (Anura: Leptodactylidae). Stud Neotrop Fauna E 26: 39-44.

BATY F, RITZ C, CHARLES S, BRUTSCHE M, FLANDROIS JP AND DELIGNETTE-MULLER ML. 2015. A Toolbox 
for Nonlinear Regression in R: The Package nlstools. J StatSoftw 66: 1-21.

BEGON M, HARPER JL AND TOWNSEND CR. 1990. Ecology, individuals, populations and communities. London: Blackwell Scientific Publications, 945 p.

BERNARDO J. 1996. Maternal effects in animal ecology. Am Zool 36: 83-105.

BERTALANFFY L VON. 1938. A quantitative theory of organic growth. Hum Biol 10: 181-213.

BERVEN KA. 1981. Mate choice in the wood frog, Rana sylvatica. Evolution 35: 707-722.

BERVEN KA. 1982a. The genetic basis of altitudinal variation in the wood frog Rana sylvatica. I. An experimental analysis of life history traits. Evolution 36: 962-983.

BERVEN KA. 1982b. The genetic basis of altitudinal variation in the frog Rana sylvatica II. An experimental analysis of larval development. Oecologia 52: 360-369.

BEVERTON RJH AND HOLT SJ. 1957. On the dynamics of exploited fish populations. London: Fishery Invest Ser II, Vol. XIX, Ministry of Agriculture, Fisheries, and Food, $533 \mathrm{p}$.

BLANCKENHORN WU. 2000. The evolution of body size: what keeps organisms small? Q Rev Biol 75: 385-407.

BOULENGER GA. 1894. XXXVIII.-List of reptiles and batrachians collected by Dr. J. Bohls near Asuncion, Paraguay. J Nat Hist 13: 342-348.

BROWN JH, MARQUET PA AND TAPER ML. 1993. Evolution of body size: consequences of an energetic definition of fitness. Am Nat 142: 573-584.

CABRERA A AND WILLINK A. 1980. Biogeografía de América Latina (Latin America Biogeography). Washington: Secretaría General de la Organización de los Estados Americanos, $122 \mathrm{p}$.

CAJADE R, MARANGONI F AND GANGENOVA E. 2013. Age, body size and growth pattern of Argenteohyla siemersi pederseni (Anura: Hylidae) in northeastern Argentina. J Nat Hist 47: 237-251.

CALDER WA. 1984. Size, function and life history. Boston: Harvard University Press, $431 \mathrm{p}$.

CARNEVALI R. 1994. Fitogeografía de la provincia de Corrientes. Corrientes: Gobierno de la Provincia de Corrientes, $324 \mathrm{p}$.

CASTANET J. 1982. Recherches sur la croissance du tissu osseux des reptiles. Application: la méthode squelettochronologique. Thèse de Doctorat d'État, Paris.

CASTANET J AND SIMIRINA E. 1990. Introduction to the skeletochronological method in amphibians and reptiles. Ann Sci Nat Zool Paris 11: 191-196.

CEI JM. 1980. Amphibians of Argentina. Monitore Zoologico Italiano n.s. Monografia 2: 609.

COGĂLNICEANU D, ROŞIORU D, SZEKELY P, SZEKELY D, BUHACIUC E, STĂNESCU F AND MIAUD C. 2014. Age and body size in populations of two syntopic spadefoot toads (genus Pelobates) at the limit of their ranges. J Herp 48: 537-545.

CRUMP ML. 1974. Reproductive strategies in a tropical anuran community. Miscellaneous publication, University of Kansas, Museum of Natural History 61: 1-68.

CRUMP ML. 1995. Leptodactylus bufonius (NCN). Reproduction. Herpetol Rev 26: 97-98.

DE-CARVALHO CB, FREITAS EB, FARIA RG, BATISTA RC, BATISTA CC, COELHO WA AND BOCCHIGLIERI A. 2008. História natural de Leptodactylus mystacinus e Leptodactylus fuscus (Anura: Leptodactylidae) no Cerrado do Brasil Central. Biota Neotrop 8: 105-115.

DE LA ESPADA JM. 1875. Vertebrados del viaje al Pacifico verificado de 1862 a 1865 por una comision de naturalistas enviada por el gobierno Español. Batracios. Madrid, 208 p.

DE SÁ RO, GRANT T, CAMARGO A, HEYER RW, PONSSA ML AND STANLEY E. 2014. Systematics of the Neotropical genus Leptodactylus Fitzinger, 1826 (Anura: Leptodactylidae): phylogeny, the relevance of non-molecular evidence, and species accounts. S Am J Herpetol 9: S1-S128.

DÍAZ-PANIAGUA C AND MATEO JA. 1999. Geographic variation in body size and life-history traits in Bosca's newt (Triturusboscai). Herpetol J 9: 21-27.

DUELLMAN WE. 1970. The hylid frogs of Middle America. Monographs, Museum of Natural History, University of Kansas 1: 1-753.

DUELLMAN WE AND CRUMP ML. 1974. Speciation in frogs of the Hyla parviceps group in the upper Amazon Basin. Occas. Pap Mus Nat Hist Univ Kansas 23: 1-40.

DUELLMAN WE AND TRUEB L. 1986. Biology of Amphibians. New York: MacGraw-Hill, 670 p.

DURÉ M AND KEHR A. 2004. Influence of microhabitat on the trophic ecology of two leptodactylids from northeastern Argentina. Herpetologica 60: 295-303.

FAGGIONI G, SOUZA F, UETANABARO M, LANDGREFFILHOP, FURMAN JAND PRADO C. 2017. Reproductive biology of the nest building vizcacheras frog Leptodactylus bufonius (Amphibia, Anura, Leptodactylidae), including a description of unusual courtship behaviour. Herpetol J 27: 73-80.

FITZINGER LJ. 1826. Neue Classification der Reptilien nach ihren Natürlichen Verwandtschaften nebst einer Verwandtschafts - Tafel und einem Verzeichnisse der Reptilien - Sammlung des K.K. Zoologischen Museums zu Wien. J.G. Heubner, Wien.

GIARETTA AA AND KOKUBUM MN DE C. 2003. Reproductive ecology of Leptodactylus furnarius Sazima \& Bokermann, 1978, a frog that lays eggs in underground chambers (Anura: Leptodactylidae). Herpetozoa 16: 115126.

GIBBONS MM AND MCCARTHY TK. 1986. The reproductive output of frogs Rana temporaria (L.) with 
particular reference to body size and age. J Herpetol 209: 579-593.

HALLIDAY TR AND TEJEDO M. 1995. Intrasexual selection and alternative mating behaviour. In: Heatwole $\mathrm{H}$ and Sullivan BK (Eds), Amphibian Biology, Social Behaviour, p. 419-468.

HALLIDAY TR AND VERRELL P. 1988. Body size and age in amphibians and reptiles. J Herpetol 22: 253-265.

HECTOR KL AND NAKAGAWA S. 2012. Quantitative analysis of compensatory and catch-up growth in diverse taxa. J Anim Ecol 81: 583-593.

HEMELAAR A. 1985. An improved method to estimate the number of year rings resorbed in phalanges of Bufo bufo (L.) and its implications to populations from different latitudes. Amphibia-Reptilia 6: 323-341.

HEMELAAR A. 1988. Age, growth and other population characteristics of Bufo bufo from different latitudes and altitudes. J Herpetol 22: 369-388.

HEYER WR. 1978. Systematics of the fuscus group of the frog genus Leptodactylus (Amphibia, Leptodactylidae). Nat Hist Mus LA 29: 1-85.

HOWARD RD. 1980. Mating behaviour and mating success in wood frogs Rana sylvatica. Anim Behav 28: 705-716.

KAPLAN RH. 1998. Maternal effects, developmental plasticity, and life history evolution. In: Mousseau TE and Fox CW (Eds), Maternal effects as adaptations. New York: Oxford University Press, New York, USA, p. 244-260.

LAUGEN AT, LAURILA A, JÖNSSON KI, SÖDERMAN F AND MERILÄ J. 2005. Do common frogs (Rana temporaria) follow Bergmann's rule? Evol Ecol Res 7: 717-731.

LAVILLA E, HEYER R, KWET A AND LANGONE J. 2004. Leptodactylus latinasus. The IUCN Red List of Threatened Species 2004: e.T57139A11590252. http://dx.doi. org/10.2305/IUCN.UK.2004.RLTS.T57139A11590252. en.

LESKOVAR C, OROMI N, SANUY D AND SINSCH U. 2006. Demographic life history traits of reproductive Natterjack Toads (Bufocalamita) vary between northern and southern latitudes. Amphibia-Reptilia 27: 365-375.

LÓPEZ JA, ANTONIAZZI CE, LLANES RE AND GHIRARDI R. 2017. Age structure, growth pattern, sexual maturity, and longevity of Leptodactylus latrans (Anura: Leptodactylidae) in temperate wetlands. AmphibiaReptilia 38: 371-379.

LOVICH JE AND GIBBONS JW. 1992. A review of techniques for quantifying sexual size dimorphism. Growth Develop Aging 56: 269-281.

LUCAS EM, BRASILEIRO CA, OYAMAGUCHI HM AND MARTINS M. 2008. The reproductive ecology of Leptodactylus fuscus (Anura, Leptodactylidae): new data from natural temporary ponds in the Brazilian Cerrado and a review throughout its distribution. J Nat Hist 42: 2305-2320.

MACARTHUR R AND LEVIN SR. 1967. The limiting similarity, convergence and divergence of coexisting species. Am Nat 101: 377-385.

MACARTHUR RH. 1970. Species packing and competitive equilibrium for many species. Theor Popul Biol 1: 1-11.

MARAGNO FP AND CECHIN SZ. 2009. Reproductive biology of Leptodactylus fuscus (Anura, Leptodactylidae) in the subtropical climate, Rio Grande do Sul, Brazil. Iheringia Sér Zool 99: 237-241.

MARANGONI F. 2006. Variación clinal en el tamaño del cuerpo a escala microgeográfica en dos especies de anuros (Pelobates cultripes y Bufo calamita). PhD thesis, Sevilla, Spain, Universidad de Sevilla, 298 p.

MARANGONI F, BARRASSO DA, CAJADE R AND AGOSTINI G. 2012. Body size, age and growth pattern of Physalaemus fernandezae (Anura: Leiuperidae) of Argentina. NW J Zool 8: 63-71.

MARANGONI F, SCHAEFER EF, CAJADE RAND TEJEDO M. 2009. Growth marks formation and chronology of two neotropical anuran species. J Herpetol 43: 446-450.

MARANGONI F AND TEJEDO M. 2008. Variation in body size and metamorphic traits of Iberian spade foot toads over a short geographic distance. J Zool Lond 275: 97-105.

MARTINS M. 1988. Biología reprodutiva de Leptodactylus fuscus em BoaVista, Roraima (Amphinia: Anura). Rev Bras Biol 48: 969-977.

MEDIACYBERNETICS. 1993-1994. Image-Pro Plus. Version 4.5.0.29. Media Cybernetics, Silver Spring, Maryland, USA.

METCALFE NB AND MONAGHAN P. 2003. Growth versus lifespan: perspectives from evolutionary ecology. Exp Gerontol 38: 935-940.

MIAUD C, GUYETANT R AND ELMBERG J. 1999. Variations in life-history traits in the common frog Rana temporaria (Amphibia, Anura): a literature review and new data from the French Alps. J Zool 249: 61-73.

MONNET JM AND CHERRY MI. 2002. Sexual size dimorphism in anurans. P Roy Soc Lond B Bio 269: 23012307.

OGLE DH. 2018. FSA: Fisheries Stock Analysis. R package version 0.8.18.

OLIVEIRA FILHO JC AND GIARETTA AA. 2008. Reproductive behavior of Leptodactylus mystacinus (Anura, Leptodactylidae) with notes on courtship call of other Leptodactylus species. Iheringia Sér Zool 98: 508515.

PIANKA ER. 1975. Niche relations of desert lizards. In: Cody ML and Diamond JM (Eds), Ecology and Evolution of Communities. Boston: Harvard University Press, Massachusetts, USA, p. 292-314. 
PONSSA ML AND BARRIONUEVO JS. 2012. Sexual dimorphism in Leptodactylus latinasus (Anura, Leptodactylidae): nasal capsule anatomy, morphometric characters and performance associated with burrowing behavior. Acta Zool-Stockholm 93: 57-67.

PRADO CPA, UETANABARO M AND LOPES FS. 2000. Reproductive strategies of Leptodactylus chaquensis and L. podicipinus in the Pantanal, Brazil. J Herpetol 34: 135139.

QUIROGA LN, SANABRIA EA AND MARANGONI F. 2015. Sexual size dimorphism and age in Odontophrynus cf. barrioi (Anura: Odontophrynidae) from the Monte Desert, Argentina. J Herpetol 49: 627-632.

RÄSÄNEN K, LAURILA A AND MERILÄ J. 2003. Geographic variation in acid stress tolerance of the moor frog, Rana arvalis. II. Adaptive maternal effects. Evolution 57: 363-371.

RÄSÄNEN K, LAURILA A AND MERILÄ J. 2005. Maternal investment in egg size: environment- and populationspecific effects on offspring performance. Oecologia 142: 546-553.

READING CJ AND JOFRÉ GM. 2003. Reproduction in the nest building vizcacheras frog Leptodactylus bufonius in central Argentina. Amphibia-Reptilia 24: 415-427.

RODRIGUES DJ, UETANABARO M AND PRADO CPA. 2004. Seasonaland ontogenetic variation in diet composition of Leptodactylus podicipinus (Anura, Leptodactylidae) in the southern Pantanal, Brazil. Rev Esp Herpetol 2004: 19-28.

ROFF D. 1993.The evolution of life histories. New York: Chapman and Hall, $535 \mathrm{p}$.

SAGOR ES, OULLET M, BARTEN E AND GREEN DM. 1998. Skeletochronology and geographic variation in age structure in the wood Frog, Rana sylvatica. J Herpetol 34: 469-474.

SCHAEFER EF. 2007. Restricciones cuantitativas asociadas con los modos reproductivos de los anfibios en áreas de impacto por la actividad arrocera en la provincia de Corrientes. PhD thesis, La Plata, Buenos Aires, Argentina, Universidad Nacional de La Plata.

SCHAEFER EF, HAMANN MI, KEHR AI, GONZÁLEZ CE AND DURÉ MI. 2006. Trophic, reproductive and parasitological aspects of the ecology of Leptodactylus chaquensis (Anura: Leptodactylidae) in Argentina. Herpetol J 16: 387-394.

SCHMIDT-NIELSEN K. 1984. Scaling. Why is animal size so important? New York: Cambridge University Press, 241 p.

SHINE R. 1979. Sexual selection and sexual dimorphism in the Amphibia. Copeia 1979: 297-306.

SHOEMAKER VH AND MCCLANAHAN LL. 1973. Nitrogen excretion in the larvae of a land nesting frog (Leptodactylus bufonius).Comp Biochem Physiol 44A: 1149-1156.
SILVA WR, GIARETTA AA AND FACURE KG. 2005. On the natural history of the South American pepper frog, Leptodactylus labyrinthicus (Spix, 1824) (Anura: Leptodactylidae). J Nat Hist 39: 555-566.

SINSCH U. 2015. Skeletochronological assessment of demographic life-history traits in amphibians. Herpetol J 25: 5-13.

SINSCH U, OROMI N AND SANUY D. 2007. Growth marks in Natterjack Toad (Bufocalamita) bones: histological correlates of hibernation and aestivation periods. Herpetol J 17: 129-137.

SINSCH U, PELSTER B AND LUDWIG G. 2015. Largescale variation of size-and age-related life-history traits in the common frog: a sensitive test case for macroecological rules. J Zool 297: 32-43.

SMIRINA EM. 1972. Annual layers in bones of Rana temporaria. Zool Zh 51: 1529-1534.

STATSOFT. 2001. Statistica (Data analysis software system). Version 6. StatSoft, Tulsa.

STEARNS SC. 1992. The evolution of life histories. Oxford: Oxford University Press, 249 p.

STEARNS SC. 2000. Life history evolution: successes, limitations, and prospects. Naturwissenschaften 87: 476486.

TEJEDO M. 1988. Fighting for females in the toad Bufo calamita is affected by the operational sex ratio. Anim Behav 36: 1765-1769.

TEJEDO M, REQUES R AND ESTEBAN M. 1997. Actual and osteochronological estimated age of natterjack toads (Bufo calamita). Herpetol J 7: 81-82.

TEJEDO M, SEMLITSCH RD AND HOTZ H. 2000. Covariation of morphology and jumping performance in newly metamorphosed water frogs: effects of larval growth history. Copeia 2000: 448-458.

TOFT CA. 1980. Feeding ecology of thirteen syntopic species of anurans in a seasonal tropical environment. Oecologia 45: 131-141.

TOFT CA. 1981. Feeding ecology of Panamanian litter anurans: patterns in diet and foraging mode. J Herpetol 15: 139-144.

VAIRA M ET AL. 2012. Categorización del estado de conservación de los anfibios de la República Argentina. Cuad Herpetol (AHA) 26: 131-159.

VERA MC AND PONSSA ML. 2014. Skeletogenesis in anurans: cranial and postcranial development in metamorphic and postmetamorphic stages of Leptodactylus bufonius (Anura: Leptodactylidae). Acta Zool-Stockholm 95: 44-62.

ZINA J AND HADDAD CFB. 2005. Reproductive activity and vocalizations of Leptodactylus labyrinthicus (Anura: Leptodactylidae) in southeastern Brazil. Biota Neotrop 5: $1-11$. 


\section{APPENDIX A}

Species, location and registration numbers of all individuals deposited and measured at the Collection of the Laboratorio de Genética Evolutiva, Instituto de Biología Subtropical (CONICET-UNaM), Posadas, Misiones, Argentina (LGE):

L. bufonius: Charata, Chaco: 05226, 05235, 05236, 05247, 05248, 05249, 05250, 05251, 05252, 05253, 05254. Perichón, Corrientes: 20058, 20059, 20060, 20061, 20062, 20063, 20064, 20065, 20066, 20067, 20068, 20069, 20070, 20071, 12163, 12947, 12948, 12949, 12950, 12951, 13330, 13419, 13437, 13438, 13439, 13440. Fuerte Esperanza, Chaco: 13006, 05863, 05864, 05865, 05866, 05867, 05868, $05869,05870,05871,05872,05873,05874,05875$, 05876, 05877, 05878, 05879, 05880, 05881, 05882, 05883, 05886, 05887, 05888, 05889, 05890, 05891, 05892, 05893, 05894, 05895, 05896, 05897, 05898,
05899, 13022, 13078, 13079, 13317, 13370, 13371, 13373, 13405, 50898, 5899.

L. latinasus: Perichón, Corrientes: 20072, 20073, 20074, 20075, 20076, 20077, 20078, 20079, 20080, 20081, 20082, 20083, 20084, 20085, 20086, 20087.

L. laticeps: Chaco, Formosa: 12083, 12084, 12100, 12101, 12150, 12164, 15282, 15283, 15284, $15285,15286,15287,15289,15290,15291,15292$, 15293, 15294.

L. furnarius: Corrientes and Misiones: 03438, 03439, 03493, 03666, 03867, 04119, 04163, 04694, 07889,12854, 12855, 12856, 12857.

L. plaumanni: Misiones: 02067, 03373, 03374, 03375, 03386, 03427, 03430, 03431, 03537, 03543, 03545, 03546, 03556, 03557, 03929, 03930, 04243, 04244, 04823, 05086, 05104, 07034, 07077, 09662, 09663, 09664, 09665, 09666, 09667, 09668, 09669, 09672, 09673, 09674, 09675, 19927.

\section{APPENDIX B}

Average SVL of males and females of the $\mathbf{1 3}$ species of the genus Leptodactylus and the SDI computed for each population. \# = species belong to the L. fuscus group. LGE = Collection of the Laboratorio de Genética Evolutiva, Instituto de

Biología Subtropical (CONICET-UNaM), Posadas, Misiones, Argentina. Mean \pm SD. $n=$ sample size. Significant differences in SVL between males and females $(P<0.05)$ are marked with $* ;{ }^{\wedge}=$ not analyzed.

\begin{tabular}{|c|c|c|c|c|c|c|}
\hline Species & Country & Coordinates & Males SVL & Females SVL & SDI & Source \\
\hline L. bufonius \# & Argentina & $29^{\circ} 48^{\prime} \mathrm{S}, 64^{\circ} 43^{\prime} \mathrm{W}$ & $56.40 \pm 2.58(62)$ & $60.00 \pm 2.87(53)$ & $1.06^{*}$ & $\begin{array}{l}\text { Reading and Jofré } \\
2003\end{array}$ \\
\hline L. bufonius \# & Several & Several & $51.60 \pm 2.0$ & $53.60 \pm 2.3$ & $1.04 *$ & Heyer 1978 \\
\hline L. bufonius \# & Argentina & $\begin{array}{l}27^{\circ} 17^{\prime} 34.8^{\prime \prime} \mathrm{S}, \\
61^{\circ} 09^{\prime} 01.4 ” \mathrm{~W}\end{array}$ & $46.68 \pm 1.02(9)$ & $45.69 \pm 1.76(3)$ & -1.02 & LGE \\
\hline L. bufonius \# & Argentina & $\begin{array}{l}25^{\circ} 04^{\prime} 39.24^{\prime \prime} \mathrm{S}, \\
61^{\circ} 37^{\prime} 52.33^{\prime \prime} \mathrm{W}\end{array}$ & $53.26 \pm 3.05(36)$ & $59.87 \pm 3.64(10)$ & $1.12 *$ & LGE \\
\hline L. bufonius \# & Argentina & $27^{\circ} 30^{\prime} \mathrm{S}, 58^{\circ} 45^{\prime} \mathrm{W}$ & $44.20 \pm 4.2(12)$ & $43.80 \pm 6.9(8)$ & -1.01 & Duré and Kehr 2004 \\
\hline L. bufonius \# & Argentina & $27^{\circ} 26^{\prime} \mathrm{S}, 58^{\circ} 44^{\prime} \mathrm{W}$ & $46.10 \pm 1.94$ & $47.90 \pm 2.32$ & 1.04 & Schaefer 2007 \\
\hline L. bufonius \# & Argentina & $\begin{array}{l}27^{\circ} 25^{\prime} 53.2^{\prime \prime} \mathrm{S}, \\
58^{\circ} 44^{\prime} 44.8^{\prime \prime} \mathrm{W}\end{array}$ & $55.30 \pm 1.8(56)$ & $56.33 \pm 2(9)$ & 1.02 & Present study \\
\hline L. bufonius \# & Brazil & $\begin{array}{l}21^{\circ} 42^{\prime} 39^{\prime \prime} \mathrm{S}, \\
57^{\circ} 43^{\prime} 16^{\prime \prime} \mathrm{W}\end{array}$ & $46.03 \pm 2.91(25)$ & $47.66 \pm 3.11(31)$ & $1.04 *$ & Faggioni et al. 2017 \\
\hline L. chaquensis & Brazil & $57^{\circ} 00^{\prime} \mathrm{W}, 19^{\circ} 34^{\prime} \mathrm{S}$ & $71.34 \pm 5.11$ & $71.31 \pm 4.51(50)$ & -1.00 & Prado et al. 2000 \\
\hline L. chaquensis & Argentina & $27^{\circ} 30^{\prime} \mathrm{S}, 58^{\circ} 45^{\prime} \mathrm{W}$ & $62.90 \pm 5.43(21)$ & $65.30 \pm 7.82(14)$ & 1.04 & Schaefer et al. 2006 \\
\hline L. chaquensis & Argentina & $27^{\circ} 26^{\prime} \mathrm{S}, 58^{\circ} 44^{\prime} \mathrm{W}$ & $63.00 \pm 5.45(27)$ & $61.38 \pm 7.67(35)$ & -1.03 & Schaefer 2007 \\
\hline L. elenae \# & Several & Several & $42.70 \pm 2.5$ & $42.80 \pm 3.1$ & $1.00 *$ & Heyer 1978 \\
\hline L. furnarius & Brazil & $18^{\circ} 55^{\prime} \mathrm{S}, 48^{\circ} 17^{\prime} \mathrm{W}$ & $38.00 \pm 1.13(19)$ & $42.40 \pm 1.58(52)$ & $1.12 *$ & $\begin{array}{c}\text { Giaretta and } \\
\text { Kokubum } 2003\end{array}$ \\
\hline L. furnarius & Argentina & Several & $36.62 \pm 1.70(11)$ & $41.79 \pm(2)$ & $1.14^{\Delta}$ & LGE \\
\hline
\end{tabular}


APPENDIX B (continuation)

\begin{tabular}{|c|c|c|c|c|c|c|}
\hline Species & Country & Coordinates & Males SVL & Females SVL & SDI & Source \\
\hline L. fuscus & Brazil & - & $43.60 \pm 2.4(135)$ & $45.60 \pm 2.2(13)$ & $1.05^{*}$ & Lucas et al. 2008 \\
\hline L. fuscus & Brazil & - & $\begin{array}{c}43.00(39.9-46.8) \\
(28)\end{array}$ & $\begin{array}{c}43.70(41.9-46.3) \\
(28)\end{array}$ & 1.02 & $\begin{array}{l}\text { Maragno and } \\
\text { Cechin } 2009\end{array}$ \\
\hline L. fuscus & Brazil & $2^{\circ} 48^{\prime} \mathrm{N}, 60^{\circ} 12^{\prime} \mathrm{W}$ & $36.20 \pm 1.3(25)$ & $39.50 \pm 1.3(25)$ & $1.09^{*}$ & Martins 1988 \\
\hline L. fuscus & Brazil & $\begin{array}{l}16^{\circ} 13^{\prime} 50^{\prime \prime} \mathrm{S}, \\
48^{\circ} 04^{\prime} 49^{\prime \prime} \mathrm{W}\end{array}$ & $46.90 \pm 2.7(13)$ & $49.30 \pm 2.6(6)$ & $1.05^{\mathbf{\triangle}}$ & $\begin{array}{l}\text { De-Carvalho et al. } \\
2008\end{array}$ \\
\hline L. gracilis \# & Several & Several & $43.00 \pm 4.8$ & $43.00 \pm 3.7$ & 1.00 & Heyer 1978 \\
\hline L. labyrinthicus & Brazil & $18^{\circ} 55^{\prime} \mathrm{S}, 48^{\circ} 17^{\prime} \mathrm{W}$ & $\begin{array}{c}136.50 \pm 17.2 \\
(16)\end{array}$ & $\begin{array}{c}127.30 \pm 12.7 \\
(12)\end{array}$ & -1.07 & Silva et al. 2005 \\
\hline L. labyrinthicus & Brazil & $22^{\circ} 15^{\prime} \mathrm{S}, 47^{\circ} 49^{\prime} \mathrm{W}$ & $170.00 \pm 18.9(5)$ & $157.00 \pm 10.4(5)$ & -1.08 & $\begin{array}{l}\text { Zina and Haddad } \\
\qquad 2005\end{array}$ \\
\hline L. labyrinthicus & Brazil & $22^{\circ} 16^{\prime} \mathrm{S}, 47^{\circ} 42^{\prime} \mathrm{W}$ & $\begin{array}{c}152.30 \pm 10.6 \\
(10)\end{array}$ & $155.00 \pm 12.3(8)$ & 1.02 & $\begin{array}{l}\text { Zina and Haddad } \\
2005\end{array}$ \\
\hline L. laticeps & Argentina & Several & $94.61 \pm 3.00(8)$ & $99.32 \pm 10.2(10)$ & 1.05 & LGE \\
\hline L. latinasus & Several & Several & $31.20 \pm 1.7$ & $33.00 \pm 1.9$ & $1.06^{*}$ & Heyer 1978 \\
\hline L. latinasus & Argentina & - & $30.30 \pm 0.9(7)$ & $32.20 \pm 2.2(6)$ & $1.06^{\mathbf{\Lambda}}$ & $\begin{array}{c}\text { Ponssa and } \\
\text { Barrionuevo } 2012\end{array}$ \\
\hline L. latinasus & Argentina & $\begin{array}{l}30^{\circ} 00^{\prime} 10.83 " \mathrm{~S} \\
57^{\circ} 22^{\prime} 31.61 " \mathrm{~W}\end{array}$ & $30.43 \pm 1.67(21)$ & $32.59 \pm 1.65$ (19) & 1.07 & $\begin{array}{l}\text { R. Cajade and J.M. } \\
\text { Piñeiro, unpublished } \\
\text { data }\end{array}$ \\
\hline L. latinasus & Argentina & $27^{\circ} 26^{\prime} \mathrm{S}, 58^{\circ} 44^{\prime} \mathrm{W}$ & $28.35 \pm 1.62(60)$ & $29.30 \pm 1.92(50)$ & $1.03 *$ & Schaefer 2007 \\
\hline L. latinasus & Argentina & $27^{\circ} 3^{\prime} \mathrm{S}, 58^{\circ} 45^{\prime} \mathrm{W}$ & $27.76 \pm 2.2(43)$ & $28.50 \pm 2.4(27)$ & 1.02 & Duré and Kehr 2004 \\
\hline L. latinasus & Argentina & $\begin{array}{l}27^{\circ} 25^{\prime} 53.2 ” \mathrm{~S}, \\
58^{\circ} 44^{\prime} 44.8^{\prime \prime} \mathrm{W}\end{array}$ & $32.38 \pm 2.94(34)$ & $33.02 \pm 3.15(17)$ & 1.02 & Present study \\
\hline L. latrans & Argentina & Several & $\begin{array}{c}65.41 \pm 28.84 \\
(94)\end{array}$ & $\begin{array}{c}63.59 \pm 26.72 \\
(89)\end{array}$ & -1.03 & López et al. 2017 \\
\hline L. mystacinus \# & Several & Several & $53.00 \pm 4.6$ & $56.50 \pm 2.7$ & $1.07^{*}$ & Heyer 1978 \\
\hline L. mystacinus \# & Brazil & $\begin{array}{l}16^{\circ} 13^{\prime} 50^{\prime \prime} \mathrm{S}, \\
48^{\circ} 04^{\prime} 49^{\prime \prime} \mathrm{W}\end{array}$ & $55.80 \pm 2.2(17)$ & $60.80 \pm 5.5(18)$ & $1.09^{\mathbf{\Lambda}}$ & $\begin{array}{l}\text { De-Carvalho et al. } \\
2008\end{array}$ \\
\hline L. mystacinus \# & Brazil & - & $52.90 \pm 2.8(7)$ & $57.90 \pm 3.1(6)$ & $1.09 *$ & $\begin{array}{l}\text { Oliveira Filho and } \\
\text { Giaretta } 2008\end{array}$ \\
\hline L. plaumanni & Argentina & $\begin{array}{l}26^{\circ} 13^{\prime} 15.6^{\prime \prime} \mathrm{S} \\
53^{\circ} 49^{\prime} 16.2^{\prime \prime} \mathrm{W}\end{array}$ & $38.64 \pm 2.57(27)$ & $41.78 \pm 2.42(9)$ & $1.08^{*}$ & LGE \\
\hline L. podicipinus & Brazil & $19^{\circ} 34^{\prime} \mathrm{S}, 57^{\circ} 00^{\prime} \mathrm{W}$ & $35.19 \pm 1.34(21)$ & $39.47 \pm 2.13(36)$ & $1.12^{*}$ & Prado et al. 2000 \\
\hline L. podicipinus & Brazil & $19^{\circ} 34^{\prime} \mathrm{S}, 57^{\circ} 00^{\prime} \mathrm{W}$ & $32.20 \pm 3.4(55)$ & $38.00 \pm 3.7(53)$ & $1.18^{凶}$ & $\begin{array}{l}\text { Rodrigues et al. } \\
2004\end{array}$ \\
\hline
\end{tabular}

